\title{
Global Languages in the Time of the Opium Wars: The Lost Idioms of Amitav Ghosh's Sea of Poppies
}

\section{Lise Guilhamon}

\section{(2) OpenEdition \\ 1 Journals}

Electronic version

URL: https://journals.openedition.org/ces/7875

DOI: $10.4000 /$ ces.7875

ISSN: 2534-6695

Publisher

SEPC (Société d'études des pays du Commonwealth)

\section{Printed version}

Date of publication: 1 September 2011

Number of pages: $67-76$

ISSN: 2270-0633

\section{Electronic reference}

Lise Guilhamon, "Global Languages in the Time of the Opium Wars: The Lost Idioms of Amitav Ghosh's Sea of Poppies", Commonwealth Essays and Studies [Online], 34.1 | 2011, Online since 16 November 2021, connection on 01 December 2021. URL: http://journals.openedition.org/ces/7875 DOI: https://doi.org/10.4000/ces.7875

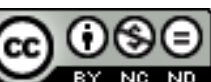

Commonwealth Essays and Studies is licensed under a Licence Creative Commons Attribution - Pas d'Utilisation Commerciale - Pas de Modification 4.0 International. 


\section{Global Languages in the Time of the Opium Wars: The Lost Idioms of Amitav Ghosh's Sea of Poppies}

Amitav Ghosh's Sea of Poppies (2008) embarks the reader on a linguistic adventure to

explore the languages and idioms which were in use at the time of the First Opium War in South Asia (1839-1842). The novel revives two idiolects which are now extinct, Laskari and the Anglo-Indian idiom, to show that the process of deterritorialization of English, which we tend to think of as an essentially contemporary phenomenon, actually has its roots in the past. This paper will attempt to disentangle these roots and situate these global idioms within the poetics of the novel and its paratextual apparatus.

In Sea of Poppies - the first volume of a projected "Ibis trilogy" - Amitav Ghosh, like some enthusiastic comparative linguist gone berserk, performs a crosscut section through the different languages and idioms spoken at one moment and in one place in the late 1830s on a former slave-ship called the Ibis, presented as a nexus of displacement, a sort of petri dish of linguistic globalization in the making. The novel is structured around this vessel that has been refitted to transport girmitiyas, indentured laborers with a signed contract (a girmit or agreement) who were taken to the imperial plantations of Madagascar, Mauritius, Fiji, or the West Indies following Britain's abolition of slavery. As in all of Amitav Ghosh's fiction, this novel combines the novelist's imagination with the anthropologist's meticulous attention to historical accuracy, and curiosity about people and places. ${ }^{1}$ The Ibis draws together a number of ill-assorted characters - seamen, convicts and coolies - which it is scheduled to transport to the Island of Mauritius. This opening novel of the trilogy, which deftly merges fiction with research and scholarship, concentrates mainly on the motley crew assembled on board the ship, and on the various roundabout ways each character has wound up on the vessel.

The most striking formal characteristic of the novel lies in the linguistic heterogeneity of the large cast of characters: the narrative interweaves the American English of Zachary, a mulatto freedman from Maryland, the Babu English of Baboo Nob Kissin, a Bengali clerk, ${ }^{2}$ the Butler English of an affluent Anglo-Indian Calcutta household (see Kachru 41), the Cantonese pidgin English of a Chinese convict named Ah-Fatt, as well as various so-called "natural" languages or dialects, such as Bhojpuri, Hindi, Bengali, Chinese and French which all chime in with one another in the narrative. These languages sometimes mix and mingle quite freely to create puns and innuendoes to repeated comic effect: surrounded by a "confusion of tongues" (SP

1. Amitav Ghosh studied history at Saint Stephen's College in Delhi, before doing a PhD in social anthropology at Oxford. His association to the Subaltern Studies movement is well known: he published an article in Subaltern Studies VII, entitled "The Slave of M.S. H.6" (published also in his collection of essays and translations, The Imam and the Indian) which formed the basis of his novel In an Antique Land.

2. In Guru English, Srinivas Aravamudan vividly defines Babu English as a lingo which "from Rudyard Kipling to Peter Sellars [...] features a singsong accent, clownish head-nodding, pretensions to erudition, credentializing anxieties, a moralistic tone, a liberal use of clichés and mixed metaphors, and incongruous literal translations into English from the vernacular" (4). See also Kachru 39. SP.

3. For greater clarity, page references to Ghosh's Sea of Poppies in this article will be preceded with the abbreviation 
61), the French Paulette adapts her idiom to every communication situation; she bends languages and mixes and creolizes them freely, recasting English in a new and inventive mould of displacement and relocation.

The narrator seems to revel in the boundless variety of languages, idioms and dialects available to him, as well as in the innumerable expressive possibilities contained within each language, and to give free rein to his unbridled linguistic facetiousness. The sheer extravagance of this linguistic crosscut section, the abounding wealth of words, sounds and meanings, compose a rich and intricate mosaic of languages, jargons and idioms. Through this linguistic extravaganza, Ghosh outlines a program - which works at the level both of poetics and of ethics - for the deterritorialization of English, a process linked to the crucial questions raised by globalization, and in particular to contemporary language issues, which tend to equate the phenomenon of the worldwide spread of English with Globish, the utilitarian, matter-of-fact and uninspired language of international communication. But Ghosh's novel shows that the process of deterritorialization of English goes beyond this trend. The diasporic point of view in the novel dramatizes the questions raised by the use of English as a language displaced by the multiplication of situations of enunciation in a "global" world, and shows that the process of deterritorialization must be understood first as an adventure in language, in which categories of meaning are constantly being broken down, shifted, and relocated.

But the narrative goes beyond this literary project of deterritorialization, which is shared by many Indian English writers today, in that it also attempts to resurrect idioms that have now become extinct: for instance, the Anglo-Indian idiom spoken by the British in India, as illustrated in the novels of Kipling or Flora Annie Steel, and Laskari, the pidgin and the specialized nautical jargon of the lascars - the Asian sailors who worked on the European schooners sailing the Indian and the Pacific Oceans for purposes of trade during the age of sail. What Ghosh is attempting to do in this novel, then, is to trace the story of early "global" languages which can perhaps be seen as forerunners of the deterritorialized englishes of today. In his 1992 novel, In an Antique Land, Ghosh pondered over the same issue and speculated that medieval traders across the Indian Ocean communicated by "using a trading argot, or an elaborated pidgin language" (281), since "common sense suggests that in an area as large and as diverse as the Indian Ocean, business could not possibly have been conducted in Tulu, Arabic, Gujarati, or indeed any tongue that was native to a single group of traders; to function at all the language of everyday business would have had to be both simpler and much more widely dispersed than any ordinary language" (280).

In Sea of Poppies, Ghosh goes one step further and attempts to actually revive idioms of this kind that have fallen into disuse, and been long forgotten. In this sense he is departing from the typically Rushdian brand of Masala English: his "Indianized English" is not only the result of a creative distortion of English or of the poetic interference of English and Hindi or Urdu; it is also an attempt to recover and resurrect idioms that have gone extinct, through a careful archaeological exhumation of different layers of language, so to speak, combined with poetic means and literary devices. Through this strategy, the narrative revives two long-forgotten idioms, AngloIndian and Laskari, and explores the sedimentation of language, the layers of history which a tongue is built on, thus illustrating Daniel Heller-Roazen's contention that: 
Language has no being beyond its drifting parts, and its sole consistency may lie in the layers of forgetting and remembrance that tie and untie it, in ever-changing ways, to those before it [...]. One might consider " $a$ " language in this sense to be a measureless mass, bearing, in each of its slates, the perceptible and the imperceptible absence of those worn away from it: the shifting sum, so to speak, of those continually subtracted from it in time. (97)

Ghosh thus attempts to map the diversity of languages that were actually spoken in South Asia in the 1830s, and to render them as faithfully as possible in the narrative. In this sense, he is being true to his own training as a historian and an anthropologist, and to the specific brand of fiction-writing which he has developed over the years, and which always mixes historical fact and fiction, breaking down the artificial boundaries between history, anthropology, geography and fiction, in an endeavor to uncover the intricate patterns and networks which constitute what Meenakshi Mukherjee calls the "co-ordinates of meaning" in Ghosh's fiction (134), the shadow lines crisscrossing through historical and geographical narratives.

This article will attempt to investigate this oscillation between fact and fiction, by comparing the novel with the paratextual apparatus which is provided or suggested by the book: I will endeavor to show how this apparatus can actually be seen as forming an inherent part of the work, and how painstaking historical research and poetic means are combined in order to give a new lease of life to long-forgotten idioms.

\section{Lexicons and glossaries}

In Seuils the literary theorist Gérard Genette defines the paratext as a threshold: it is a zone between text and off-text, a zone not only of transition but also of transaction. In other terms the paratext not only informs the reading of the text, but can also play a central role in shaping the narrative and its language. I contend that the paratext must be read as an inherent part of the creative process itself in the case of Sea of Poppies.

The most obvious paratext is directly appended to the book. The novel ends with a few pages of acknowledgments that pay tribute to the lexicographers and linguists of the past, such as Lt. Thomas Roebuck, who wrote A Laskari Dictionary or Anglo-Indian Vocabulary of Nautical Terms and Phrases, in English and Hindusthani, first published in Calcutta in 1811, revised and reissued in 1813 and 1882. Ghosh also mentions the famous Hobson-Jobson: A Glossary of Colloquial Anglo-Indian Words and Phrases, and of Kindred Terms, written by Colonel Henry Yule and A. C. Burnell and first published in 1886. These bibliographical references highlight the importance of lexical investigation for the novel.

Unlike many earlier Indian English novels, Sea of Poppies is not fitted with a glossary, nor are most of the more unfamiliar words necessarily followed by a translation or an explanation. At times, the lay reader cannot but be somewhat puzzled by the idioms reproduced in the text and this perplexity is often echoed by the characters themselves, when they do not share the same lingo as the person they are speaking to: "From what I hear the Rascal's going to be in for a samjaoing soon enough. The kubber is that his cuzzanah is running out," says the Anglo-Indian river pilot Mr. Doughty to the American Zachary. "Cu - cuzzanah? Now there you go again Mr Doughty: that's another word I don't know the meaning of” (SP 45), 
complains a baffled Zachary, only to be told that it was about time he stopped behaving like a "gudda" - "that's a donkey in case you were wondering" - and learnt the "zubben - the flash lingo of the east" (SP 45).

Amitav Ghosh has in fact provided a glossary of his own making to the novel, but it is not directly attached to the book. It is available online on his official website and on the official website of the novel. ${ }^{4}$ The glossary, entitled The Ibis Chrestomathy, is presented as having been compiled by successive generations of the descendents of one of the convicts traveling aboard the Ibis, Raja Neel Ratan. It has purportedly been put together from the notes taken down by this ancestor whose purpose it was to write a lexicon of Anglo-Indian words which, he believed, would one day become part of the English language and thereby gain the right to be admitted into the Oxford English Dictionary. ${ }^{5}$ Like the novel itself, the Chrestomathy is based on Ghosh's patient research into the Anglo-Indian and Laskari idioms, as the footnotes pages 3 to 5, which reference the Hobson Jobson and Roebuck's dictionary, confirm, but it is also playful in tone, and, like the novel, devotes a lot of space to a schoolboyish preoccupation with toilet humor.

It is revealing that in the Chrestomathy the words Neel predicts may find a place in the pantheon of words admitted into the OED are referred to as girmitiyas: words in transition, travelling from one language to another, and reinventing a new identity for themselves in the process. When a word from this lexicon is admitted into the OED it becomes marked with a + sign and is to be considered "a new coinage, with a new persona and a renewed identity" (Ghosh, Chrestomathy 2). Language itself is thus presented as a migrant, as a diasporic subject. According to a number of postcolonial scholars or writers, ${ }^{6}$ for the migrant, the experience of displacement, the moment in the hold of the ship when the diasporic subject is uprooted and transported, is also the moment when he learns to imagine communities beyond a common territorial and linguistic belonging and to invent new forms of belonging, new solidarities and relationships. Thus most of the characters in Sea of Poppies can boast of multiple, meshed identities. They constantly reinvent themselves as they shape their destinies and this is reflected, significantly, in their changes of names: for instance, the French Paulette successively becomes Putli, then Puggly, Putleshwari, and finally Pugli. Similarly, because Mr. Doughty has difficulties transcribing Indian names when taking down the list of the coolies aboard the ship, Madhu Kalua is re-christened Maddow Colver:

Later, within the dynasty that claimed its descent from him, many stories would be invented about the surname of the founding ancestors and the reasons why "Maddow"

4. Following what Vikram Chandra had done for his Sacred Games (2006), 30 September 2011 $<$ http://sacredgames.typepad.com/glossary/>.

5. In fact, Ghosh has claimed, in an interview with Salil Tripathi for Tehelka, that every single word in the novel can be found in the OED.

6. Édouard Glissant, for instance, defines the transatlantic passage in the hold of the slave-ship as the moment of radical breaking away from the past and of symbolic rebirth in his earliest non-fictional work Le discours antillais (1981, 40). The idea reappears in several of his books, Poétique de la Relation (1990) and Introduction à une poétique du divers (1996) for instance, and is also taken up by other authors, like Patrick Chamoiseau in Écrire en pays dominé: "I shall not dwell on the horror of the hold. But I will not forget it entirely, either, just so that I can understand that in the hold I went through a fathomless experience of death and of incredible rebirth" ("Passons vite sur l'horreur de la cale. Mais gardons-en l'idée, juste pour comprendre que j'y ai connu un sans-fond de mort et d'inouie renaissance" [133, my translation]). 
occurred so frequently among his descendents. While many would choose to recast their origins inventing grand and fanciful lineages for themselves, there would always remain a few who clung steadfastly to the truth: which was that those hallowed names were the result of the stumbling tongue of a harried gomusta, and the faulty hearing of an English pilot who was a little more than half-seas over. (SP 262)

This opportunity of reinventing oneself is one of the defining characteristics of the ideal diasporic subject. Similarly, the Chrestomathy implies, languages that are caught up in the colonial and diasporic processes also recast themselves through their displacement. This is why postcolonial and diasporic literatures constantly dramatize the activities of linguistic displacement - translation, transformation, creolization through word play, meaning shifts, exaggeration, or other poetic devices. Thus the Anglo-Indian idiom revived in Sea of Poppies is not merely the precise reflection of a historical linguistic context, but also a literary idiom crafted for poetic purposes.

\section{Anglo-Indian speech in the novel}

Several British characters in the novel belong to the Anglo-Indian tradition, and speak in the Anglo-Indian idiom, the variety of English which was used by the British in India at the time of the Raj and was heavily laced with Indian words whose inclusion into this idiom often resulted from the social, political and economic factors of the colonial situation, as Ivor Lewis underlines in the preface to his glossary of Anglo-Indian terms, Sabibs, Nabobs and Boxwallabs:

It has been possible from the beginning of the seventeenth to the middle of the twentieth century to associate, with varying degrees of certainty, the dates of acquiring Indian expressions broadly with the prevailing social, official, political, commercial and personal relationships existing between the Indians and the British. This is social history documented by dated lexical items appropriate to the various linguistic registers and contexts of Anglo-Indian usage. (8)

Mr. Doughty, the cantankerous river pilot who steers the Ibis into the tricky Hooghly estuary, is one such Anglo-Indian character: "Where's the mate? Has he been given the kubber that my bunder-boat has lagowed? Don't just stand there: jaw! Hop to it, before I give your ganders a taste of my lattee. Have you saying your bysmellas before you know it" (SP 23). One noteworthy characteristic of this idiom is that it absorbed a number of "Hindustani" words, but the various spellings of these words in the text are not a transcription of the Indian pronunciation. These words are spelt in Sea of Poppies the way Anglo-Indians used to (mis)pronounce and (mis)spell them, as recorded in Kipling's novels, for instance, and in a number of Anglo-Indian glossaries: in addition to Ivor Lewis's book, and to the Hobson-Jobson, readers can refer to Nigel Hankin's Hanklyn-Janklyn. A Stranger's Rumble-Tumble Guide to Some Words, Customs and Quiddities Indian and Indo-British, or George Whitworth's An Anglo-Indian Dictionary for instance. The vocabulary and morpho-syntactic forms of the words used in the short excerpt given above reveal the tight link between power and language which lies at the heart of the colonial encounter: Mr. Doughty adds tense and person inflections to the second person imperative form as if it were the root form of these verbs. For example, "my boat has lagowed" is to be understood as "my boat has been moored," from the Hindi "lagâo" (the imperative form of "lagânâ," meaning "attach, apply, join, fix"). The warping of Indian words, whether through corrupting pronunciation, or 
through grammatical distortion, is evidently a form of symbolic violence imposed upon the colonized tongue. This linguistic violence can also be revealed in certain cases where a double meaning appears, for instance in the use of the spelling "jaw" for the order "jao": "go." The word "jaw," evocative of feral violence in English, also implicitly reveals the relation of dominance that is inscribed into the use of language by the British characters. Poetics here take over from strict historical accuracy.

Sea of Poppies also features comprehensive lists of professions and everyday objects which are integrated within the narrative, and accompanied with a few brief words of explanation. For instance, the narrator draws up an inventory of the domestic servants of an Anglo-Indian household:

curiosity about the newly arrived missy-mem had spread to the bobachee-connah and many of the kitchen staff were lurking in the anterior vestibule, where the punkahwallahs sat, pulling their overhead fans by means of ropes attached to their toes: among them were the curry consumah, the caleefa who roasted the kabobs and the bobachees who were responsible for the stews and the joints of beef. The indoors servants had even contrived to smuggle in a few whose place was strictly out-of-doors - malis from the garden, syces and julibdars from the stables, durwauns from the gatehouse, and even some beasties from the gang that kept the house supplied with water. (SP 117)

Other lists draw together technical terms designating the ranks of native administrative professions in Anglo-India, such as "cranny, serishta, carcoon, munshi, mootsuddy and gomusta" (SP 150). Passages like these are rife in Sea of Poppies which consistently exploits the poetic possibilities of lexical inventories, and contribute to the general effect of linguistic defamiliarization.

A similar strategy of glossing and identification is at work when unfamiliar words are inserted within the morpho-syntactic structure of very common collocations: the reader is easily able to replace the unfamiliar word with the more common one and thus make sense of the sentence. For example, when Mrs. Burnham summons Paulette to tell her that the middle-aged and censorious Mr. Kendalbushe is desirous of securing her for his bride, she uses Anglo-Indian equivalents of common British expressions:

Can you imagine, dear, what a prodigious stroke of kismet it will be for you to bag Mr.

Kendalbushe? [...] Ever since he's lost his wife, every larkin in town's been trying to bundo him. I can tell you, dear, there's a paltan of mems who'd give their last anna to be in your jooties. (SP 251)

In other terms, every girl in town has been trying to snap up Mr. Kendalbushe and scores of memsahibs would give their last farthing to be in Paulette's shoes. This little lecture is easy enough to decipher even if the reader has no previous grounding in basic Anglo-Indian, and it is easy to perceive that the exaggerated linguistic construction here is playful rather than strictly realistic.

The poetic means mobilized by the author are thus combined with the lexical and philological excavation, made evident in the acknowledgments and the Chrestomathy, in order to revive the Anglo-Indian idiom of colonial days.

\section{The language of the lascars}

The other major paratext provided for this novel focuses on the other lost language of Sea of Poppies and is an article written by Amitav Ghosh, entitled "Of 
Fanás and Forecastles: the Indian Ocean and Some Lost Languages of the Age of Sail," which the author published in June 2008 in the Economic and Political Weekly (or $E P W$, an important Indian left-leaning magazine published in Mumbai). In this quasischolarly piece based on primary and secondary sources, Ghosh retraces the story of Indian Ocean navigators and their idioms. The term "lascar" referred indifferently to the Arabs, south Asians, Malays, east Africans, Filipinos and Chinese who worked in the crews of merchant ships of the Indian Ocean region in the age of sail. As such, the term belongs both to the nautical and the colonial contexts.

Ghosh's EPW article can be seen as a sort of gloss on the use of Laskari in the novel, which is why, again, I consider it as a paratext. The article is derived from a keynote lecture which Ghosh delivered in August 2007 at a Johannesburg conference, and the research that went into the lecture clearly formed the basis of Ghosh's preparatory work for Sea of Poppies. Characteristically, Ghosh sets out to show that present-day globalization has its roots in the past: "It is common nowadays to hear 'diversity' being spoken of as though it were some thrilling new invention. But it is unlikely that there were ever any more diverse collections of people [...] than the crews of merchant ships in the age of sail" (57). Ghosh can only surmise what idioms these motley crews could use in order to communicate:

what is more likely is that Roebuck's Laskari was used only in relation to matters pertaining to the running of the vessel. For the rest the lascars probably used, among themselves, a series of contact languages and pidgins, made up of elements of Swahili, Malay and Hindustani. To communicate with officers and white passengers - and possibly often amongst themselves as well - they probably used variants of the SinoPortuguese-English pidgin that came to be associated with the South China Coast. ${ }^{7}$ This marvellously expressive dialect once flourished in many corners of the Indian Ocean, but like Laskari it did not outlast the age of sail. (60)

In Sea of Poppies, the narrator uses a nautical metaphor to define the Laskari tongue spoken by the crew amongst themselves as:

that motley tongue, spoken nowhere but on the water, whose words were as varied as the port's traffic, an anarchic medley of Portuguese calaluzes and Kerala pattimars, Arab booms and Bengal paunchways, Malay proas and Tamil catamarans, Hindusthani pulwars and English snows - yet beneath the surface of this farrago of sound, meaning flowed as freely as the currents beneath the crowded press of boats. (96)

The idiom used by the lascars thus becomes the epitome of a diasporic tongue, a mix of various languages displaced by the multiplication of situations of enunciation in a proto-globalized world, a motley idiom that was forged in diversity and transformation, and, like the ships it was spoken on, travelled the seven seas and spread across the globe. As such, it can be seen as the forerunner of the deterritorialized englishes of today, just as the lascars were, according to Ghosh, "possibly the first Asians and Africans to participate freely, and in substantial numbers, in a globalised workspace" (EPW 58).

Ghosh's fascination with the nautical jargon of Laskari and the strange and wonderful coincidences wrought by its etymologies is evidenced in the echoes

7. This Cantonese pidgin, spoken by Ah-Fatt, the Chinese convict who is one of the secondary characters of Sea of Poppies, is more amply illustrated in the second volume of the Ibis trilogy, River of Smoke (released in June 2011), which mainly takes place in Canton, where the opium processed in India was transported and sold. 
between the novel and the EPW article: "in this process of naming, languages often met and married with picturesque results: [...] the words for the complex set of lateral masts that project forward from a ship's bows - the jib, jib-boom, etc." (59) were transformed into jīb, which means "tongue" in some Indian languages. The outermost part of the jib-boom thus became the Shaitan Jìb, the Devil's tongue. This part of the boat becomes the stage of a dramatic episode in the novel when Jodu, a newly-minted lascar, is bullied by the first mate into clambering along the jīb to arrange a rope, and almost loses his life in the process (SP 392). The power of evocation of the name is thus put to poetic use in the text.

Likewise, the evocative name given to forecastle in Laskari, the fana, suggests the "hood, as in the flared head of the cobra - and of course, if a ship were to be thought of as a creature of the sea, then this would be exactly the part of its anatomy to which the location of the fana would correspond" (EPW 60). This image is exploited metaphorically in the novel, as Jodu marvels at the magical and epic associations of the word: "Jodu was familiar with the word fana, and had often wondered what it would be like to live and sleep inside the skull of the great living creature that was the ship" (SP 171). Moreover, when languages intersect they can also produce new words or unexpected meanings, which carry poetic undertones rather than merely etymological signification: thus Zachary is renamed "Malum Zikri" by the lascar crew, which delights Paulette who explains "It means the "one who remembers"' (SP 238).

From these examples, which represent only a small selection, I hope to have shown that the novel constantly echoes, in poetic terms, the scholarly and factual writing of the article. When Ghosh published In an Antique Land, one of its paratextual companion pieces was his academic paper "The Slave of MS H.6" published in volume VII of the Subaltern Studies series. The intertextuality between In an Antique Land and Ghosh's Subaltern Studies article has been analyzed in an article by Robert Dixon, "Travelling in the West': The Writing of Amitav Ghosh," in a volume edited by Tabish Khair, Amitav Ghosh: A Critical Companion. Dixon illuminates the ways in which In an Antique Land and "The Slave of MS H.6" are caught in a dialogic relation with one another as they share a common concern with recovering Bomma-the-slave's subaltern consciousness as a "theoretical fiction," drawing on a form of "strategic essentialism" in order to provide a reading of the past which is actually a commentary on the present. Likewise, Tabish Khair's article in this collection of essays, "Amitav Ghosh's The Calcutta Chromosome: The Question of Subaltern Agency," also examines the relation between this novel and the subaltern studies movement; more specifically, he looks at the ways in which Ghosh's novel questions Eurocentric definitions of history and of science in order to restore agency to the Indian "subaltern." What these articles show, then, is that the connection between fictional literary creation and scholarly research in Ghosh's work actually goes further than the influence of a specific historiographical movement or mere intertextual echoes between his fiction and non-fiction: his novels are bound in a more fundamental and creative way to the research their historical contextualization is grounded in.

Thus, for Sea of Poppies, there are a number of identifiable intertextual links between the novel and its two major non-fictional paratexts. But fiction and non-fiction, 
literary narrative and historical narrative, are intertwined in more complex ways in Ghosh's work: his non-fiction is always shaped by a poetic drive which defies the norms and rules of academic work, while his fiction always bears the imprint of the process of research which it is founded on. His novels are not merely set in a specific time and locale, in a historical and geographical context which the author meticulously researches before writing the novel, and reproduces with an abundance of detail. It is the very process of historical research that is woven into the fabric of the narrative (notably through the repeated use of the motif of the quest which structures virtually every novel by Ghosh), while conversely poetic and narrative devices are widely mobilized in his non-fictional works.

The exuberant evocation of the boundless diversity of languages (both local and global) in Sea of Poppies is forged in the work of literature but also relies on factual research. The fruitful transaction between two types of writing, scholarly and literary, which crumbles the boundaries between anthropological, historical and fictional narratives, emphasizes the inherent heterogeneity of Ghosh's writing which, in this sense, can be described as quintessentially postcolonial: the narrator is always speaking from multiple sites of enunciation, as anthropologist, historian and fiction-writer, foregrounding his own position and confronting different frames of reference, which overlap but never entirely coincide, which are different yet never radically incommensurable. Ghosh's painstaking exploration of the history of emerging global languages in the Age of Sail must be understood allegorically as a comment on the spread of English as an international language today. The rich and diverse possibilities offered by the history of the English language and by the various transformations it underwent in former colonies of the British Empire are exploited poetically in Ghosh's novel in order to challenge a hegemonic and purely anglocentric vision of "Globish" which ignores the complexity of shifting linguistic power-structures today

Lise GuILHAMON, Université de Versailles - St Quentin

\section{Works Cited}

Aravamudan, Srinivas. Guru English: South Asian Religion in a Cosmopolitan Language. Princeton: Princeton UP, 2006.

Chamoiseau, Patrick. Écrire en pays dominé. Paris: Gallimard, 1997.

Chamoiseau, Patrick and Raphaël Confiant. Lettres créoles. Paris: Gallimard, 1999.

DIXON, Robert. “'Travelling in the West': The Writing of Amitav Ghosh.” Khair 9-35.

GeneTte, Gérard. Seuils. Paris: Seuil, 1987.

GHOSH, Amitav. The Ibis Chrestomathy. 14 June 2011

<http://www.amitavghosh.com/latest/ibis_chrestomathy.pdf >.

-. In an Antique Land. New Delhi: Permanent Black, 1992.

- . "Of Fanás and Forecastles: The Indian Ocean and Some Lost Languages of the Age of Sail." Economic and Political Weekly (21 June 2008): 56-63.

—. River of Smoke. London: John Murray, 2011.

9. See Alexis Tadié: "Investigation - whether it be of the historical or the detective variety - is the narrative structure which characterizes all of Ghosh's writing. [...] Hence the obsessive quest which seems to push every one of Ghosh's novels forward in order to find again the meaning of story-telling, to understand through narration the import of events and the implication of characters in the world" ("L'enquête, historique comme policière, caractérise la manière de Ghosh. [...] D'où cette obsession du roman de Ghosh qui pousse celui-ci à retrouver le sens des histoires, à essayer de comprendre par la narration la portée des événements, et l'imbrication des personnages dans le monde" [67, my translation]). 
-. Sea of Poppies. London: John Murray, 2008.

—. "The Slave of M.S. H.6." 1992. The Imam and the Indian. New Delhi: Permanent Black, 2002. 169-242.

GLISSANT, Édouard. Le discours antillais. 1981. Paris: Gallimard, 1997.

—. Introduction à une poétique du divers. Paris: Gallimard, 1996.

- Poétique de la relation. Paris: Gallimard, 1990.

Hankin, Nigel. Hanklyn-Janklyn. A Stranger's Rumble-Tumble Guide to Some Words, Customs and Quiddities Indian and Indo-British. New Delhi: Tara-India Research, 2003.

HelLer-RoAzen, Daniel. Echolalias. On the Forgetting of Language. New York: Zone, 2005.

KaChru, Braj B. Asian Englishes: Beyond the Canon. Hong Kong: Hong Kong UP, 2005.

KHAIR, Tabish. "Amitav Ghosh's The Calcutta Chromosome: The Question of Subaltern Agency." Amitav Ghosh: A Critical Companion. Ed. Tabish Khair. New Delhi: Permanent Black, 2003. 142-61.

LEWIS, Ivor. Sabibs, Nabobs and Boxwallabs: A Dictionary of the Words of Anglo-India. New Delhi: Oxford UP, 1991.

MukHERJEE, Meenakshi. "Maps and Mirrors: Co-ordinates of Meaning in The Shadow Lines." The Perishable Empire. Essays on Indian Writing in English. New Delhi: Oxford UP, 2000. 134-48.

SPIVAK, Gayatri Chakravorty, "Subaltern Studies: Deconstructing Historiography." Subaltern Studies IV: Writings on South Asian History and Society. Ed. Ranajit Guha. New Delhi: Oxford UP, 1985. n. p.

TADIÉ, Alexis. “Amitav Ghosh, les nuances de l'histoire.” Esprit 1 (Janvier 2002): 62-73.

TRIPATHI, Salil. "Modern India was built on a drug." Tehelka 5.20 (24 May 2008). 14 June 2011 <http://www.tehelka.com/story_main39.asp?filename=hub240508modern_india_on_ drug.asp $>$.

WhitworTh, George Clifford. An Anglo-Indian Dictionary: A Glossary. London: Kegan Paul, 1885. Facsimile reprint. Gurgaon: Indian Documentation Service, 1976.

Yule, Henry, and A. C. BuRnell. Hobson-Jobson: A Glossary of Anglo-Indian Colloquial Words and Phrases and of Kindred Terms. 1886. New Delhi: Munshiram Manoharlal, 2000. 